Journal of Agri-Food Science and Technolgy

Journal homepage http://journal2.uad.ac.id/index.php/jafost

\title{
EFFECT OF PEANUT TYPES ON PATTIES ANALOGUE CHARACTERISTICS
}

\author{
Nur Annisa Metya Novikasari ${ }^{1}$, Anita Kurnia Wati ${ }^{1}$, Nur Khikmah ${ }^{1}$, Iffah Muflihati ${ }^{1}$ \\ ${ }^{1}$ Food Technology Study Program, FTI, Universitas PGRI, Semarang, Indonesia \\ Corresponding Author: nmetyan@gmail.com
}

\begin{tabular}{l} 
ARTICLE INFO \\
\hline Keywords: \\
Mung Bean \\
Kidney Bean \\
Peanut \\
Patties Analog
\end{tabular}

ABSTRACT

Patties analogs are products made from vegetable protein that is not from meat but resembles the nature of meat. Patties analog has several features, including being made or formulated so that the nutritional value is higher than the original meat. The purpose of the study was to determine the process of making patties analog, to determine the formulation of mung bean flour, kidney bean flour and peanut flour combined with wheat flour, to produce the best patties analog. Moreover, it is to determine the yield's physical, chemical, and sensory of patties analog produced. The main ingredients used are kidney bean flour, mung bean flour, and peanut flour, as well as additional ingredients such as oyster mushrooms, high protein wheat flour, and seasonings with the same percentage. Based on the analysis of the water content of the three samples, the highest value is the water content of kidney bean flour patties $(25.88 \%)$. The highest ash content is indicated by mung bean flour patties which is equal to $0.08 \%$. The highest fat content obtained by peanut patties with a value of $0.4 \%$ and the highest WHC is found in peanut patties that is $2.9867 \%$. Meanwhile, based on the organoleptic test, the most preferred patty analog by panelists is a patty made of mung bean flour.

\section{INTRODUCTION}

Imitation meat is a product composed of vegetable protein, which is not derived from meat materials, but able to resemble original characteristics of meat. Imitation meat has some features, i.e., better nutrition values, more homogenized results, preserved, customizable as to have no animal-derived fat, and lower cost (Astawan, 2009). Imitation meat has no cholesterol and low level of saturated fat so that it is consumable by people who are not allowed to consume cow meat due to health issues, also as by vegans.

Compared to the original meat, imitation meat has some features. It is customizable or can be formulated to have higher nutrition values than real meat, has more homogenized result, 
and extended expiration date (in dried); can be customized to contain no cholesterol or animalderived fat, while having high unsaturated fat which is good for health, lower-priced (30 to 50 percent cheaper than real meat), sensed by mouth as powder or fiber of real meat with its texture, and the juiciness of the meat is controllable by adjusting the water addition (which usually comes out if real meat is cooked) when cooked by mixing it with real meat. Moreover, it can be cooked as meat products such as sausages, the casing of sausages, hamburger meat, rendang, meatloaf, meatball, beefsteak, poor and other processed products (Hudaya, 1999).

Based on previous explanations, imitation meat is made of leguminous (mung bean, kidney bean, and peanut) as protein alternatives besides animal-derived protein to improve society's nutrition. The high cost of animal meats makes some people rarely consume it, although protein is necessary for bodies. Hence, low-cost imitation meat as patties analog will be an alternative to meat consumption. The research objective is to know the production process of patties analog, the formulation of mung bean, kidney bean, and peanut flour composition to make the best patty, and to define the physical, chemical, and sensory analysis result of the patties analog made.

\section{RESEARCH METHOD AND MATERIALS}

\subsection{Tools and Materials}

Materials used in patties are kidney beans, mung beans, peanuts, high protein flour, oyster mushroom, water, pepper, garlic, salt, seasonings, and CMC. Meanwhile, materials used for analysis are $N$-hexane, filter paper, yarn, and aquades or distilled water.

Tools used in the production of patties analog are blender, cabinet dryer, 60-mesh strainer, scale, gas stove, pan, baking sheet, spoon, basin, stirrer, grinder, steamer, oven, cookie press. Meanwhile, tools used for analysis are oven, aluminum cup, analytical scale, spatula, furnace, porcelain cup, soxhlet extractor, rounded bottom flask, hotplate, condenser, mohr pipette, vortex, and centrifuge machine.

\subsection{Research Method}

\subsubsection{Mung bean flour production process}

Mung beans are soaked into cold water for 24 hours. Then, the mung beans are washed and cleaned then boiled in hot water for 15 to 20 minutes. After that, the strained mung beans then dried in cabinet dryer for another 24 hours. The dried mung beans then are turned into flour by using a dry blender.

\subsubsection{Kidney bean flour production process}

Kidney beans are soaked for a whole night. Then, the kidney beans are washed in the morning. The cleaned kidney beans then are boiled in hot water for the next 15 to 20 minutes. After the kidney beans are strained, they are dried in a cabinet dryer for another 24 hours. The dried kidney beans then are turned into flour by using a dry blender.

\subsubsection{Peanut flour production process}

Peanuts are boiled for 5 minutes, then strained. Then, they are dried in a cabinet dryer for 24 hours. After that, the dried peanuts are turned into flour by using a dry blender. 


\subsubsection{Patties analog making-process}

All beans flour (mung beans, kidney beans, peanut), high protein flour (hard wheat flour), seasonings, and oyster are mixed into one. Some water, which is mixed by CMC before, is added into the mixture. The mix then is stirred well, and then the dough is kneaded until it becomes less sticky. The patties dough then is fermented for an hour. The fermented dough then is molded into the shape of a patty and then steamed for 30 minutes. The patties analog then are baked in an oven for 10 minutes in $100^{\circ} \mathrm{C}$ heat.

\subsubsection{The formulation of patties analog}

\begin{tabular}{|c|c|c|c|}
\hline \multirow{2}{*}{ Ingredients } & \multicolumn{3}{|c|}{ Treatments } \\
\hline & KB & $\mathrm{MB}$ & $\mathrm{P}$ \\
\hline Beans flour & 30 gram & 30 gram & 30 gram \\
\hline Oyster & 22,5 gram & 22,5 gram & 22,5 gram \\
\hline High protein wheat flour & 7,5 gram & 7,5 gram & 7,5 gram \\
\hline Garlic & 3 gram & 3 gram & 3 gram \\
\hline Pepper powder & 1,5 gram & 1,5 gram & 1,5 gram \\
\hline Seasonings & 3 gram & 3 gram & 3 gram \\
\hline Water & $20 \mathrm{ml}$ & $20 \mathrm{ml}$ & $20 \mathrm{ml}$ \\
\hline CMC & 0,01 gram & 0,01 gram & 0,01 gram \\
\hline
\end{tabular}

\subsubsection{Sample analysis}

The analysis of patties analog includes Oven Drying Method for water content analysis (AOAC, 1995), Graphymetric method for ash content analysis (AOAC, 2005), Soxhlet method for fat content (AOAC, 1995), WHC (Handayani et. al., 2014) and sensory analysis. The sensory analysis uses two types of evaluations. The hedonic test is applied with contrast, odor, peanut taste, savory taste, crusty textures, sandy textures, and overall contentment as parameters with a rating scale from 1 to 5. Another type of sensory analysis taken is a descriptive test with brightness intensity, odor, peanut taste, savory taste, crusty texture, and sandy texture as parameters.

\section{RESULT AND DISCUSSION}

\subsection{Water content}

The amount of water content in food determines texture, appearance, taste, and microbe's reproducibility. The water content in food affects the expiration date of food (Winarno, 2004). Analysis of variance (ANOVA) test result shows the significance level of 0.05. Furthermore, it means that the use of different beans fluor does not affect much to the water content of patties analog made. Based on observation, some characteristics are obtained as follows: 


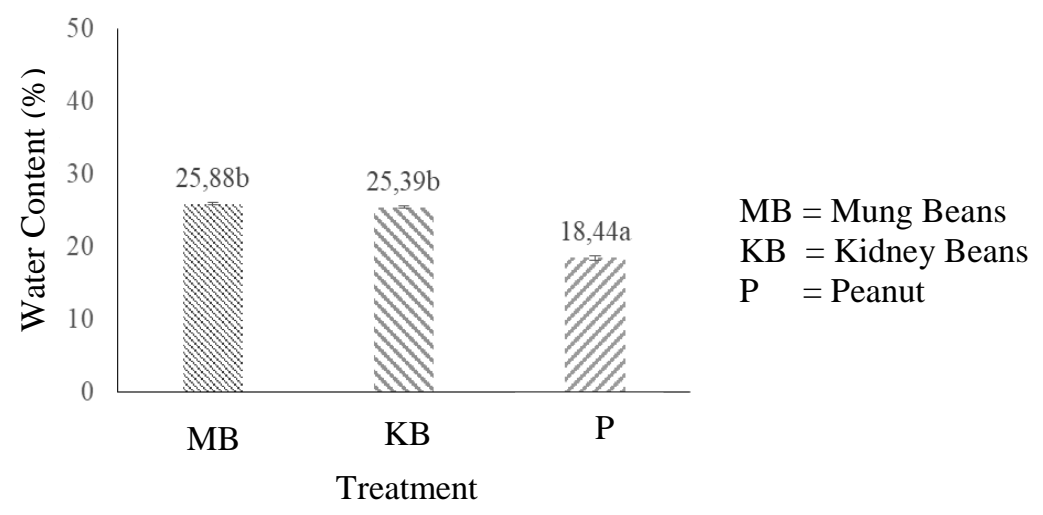

Figure 1. Water content percentage of patties analog

Based on Figure 1, the water content on the variation of the addition of kidney bean flour and mung bean flour shows an insignificant difference. However, when the peanut flour is added as variation, the water content is much less than both previously mentioned variants. The highest water content is obtained in kidney bean variant as $25.88 \%$, and the lowest is in peanut as $18.44 \%$.

According to SNI (1995), the maximum standard of water content in a meatball is $70 \%$. Hence, the water content of patties analog made in the research is much below than the maximum level of the standard, and can be said it is already fulfilled the standard of SNI 1995. Besides, according to Kudsnadi et. al. (2012), the time-duration of cooking at high temperatures may affect the shrinkage of the product. It is caused by protein denaturation and decreased water holding capacity so the best cooking temperature for meatball production is 70 to 90 degrees Celcius.

\subsection{Ash content}

Ash is an organic compound as a combustion result of any organic material. According to Sudarmadji (1989), ash content and its composition depends on the type of material and the process of combustion, and relates to the mineral composition of a material. Analysis of variance (ANOVA) test result shows the significance level of 0.05 . Furthermore, it means that the use of different beans fluor does not affect much to the ash content of patties analog made. Based on Figure 2, the addition of kidney bean, mung bean, and peanut flour shows no significant difference. The insignificance is because of the mineral composition of the filling used in the patty is more than the protein. If there are more fillings used in the production process of a kidney bean meat analog, the higher the ash content is (Nurhadi, 2010). Besides, the type of wheat flour used, which is a high protein one, caused the patty tends to absorb water due to the characteristics of a starch (Koswara, 1995). Meanwhile, according to (Gomes et al., 2002) the amount of ash content of gelatin is profoundly affected by chemical consentration. High chemical concentration may result in over hydrolysis, the disappearance of protein molecules, and inessential mineral sediment. 


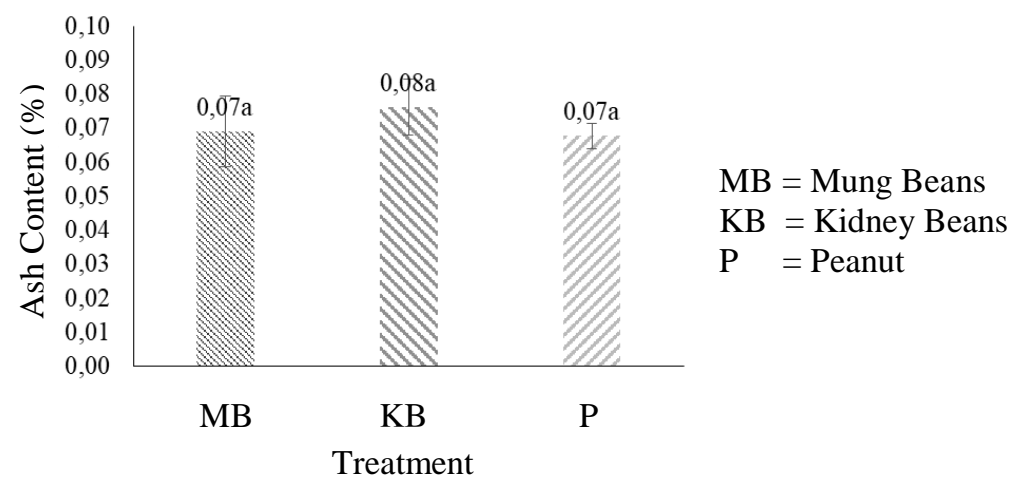

Figure 2. Ash content percentage of patties analog

Based on the test result, the highest ash content is found in the variant of mung bean flour $(0.07 \%)$, followed with kidney bean flour and peanut flour variants $(0.06 \%)$. All results already under the maximum level of 3\% ash content percentage as in SNI 1995.

\subsection{Fat content}

Fat and oil are one of the lipids, which are only soluble in organic solvents (ether, benzene, and chloroform). Generally, fat is defined as triglyceride which is solid at room temperature (Wayuningsih, 2014). Analysis of variance (ANOVA) test result shows the significance level of 0.05 . Furthermore, it means that the use of different beans fluor does not affect much to the fat content of patties analog made. Based on observation, some characteristics are obtained as follows:

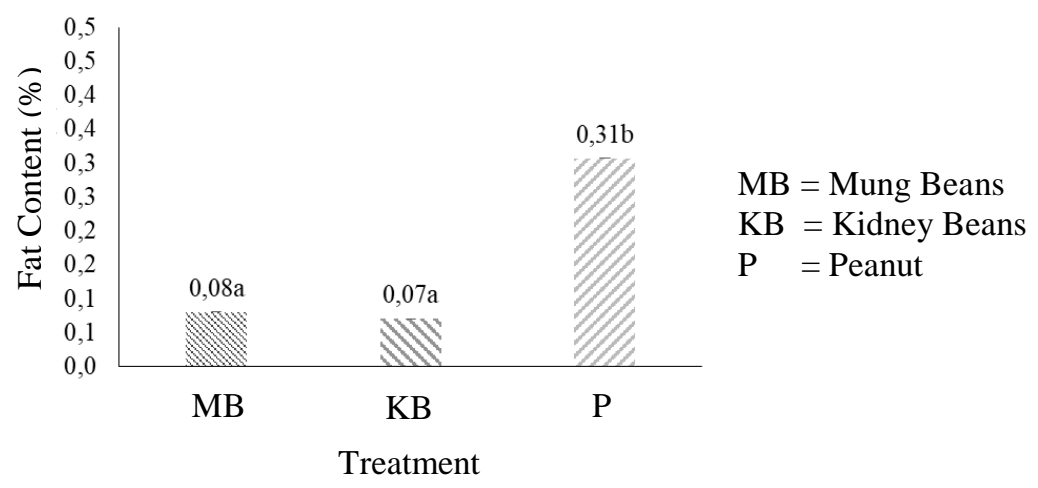

Figure 3. The fat content of patties analog.

Based on Figure 3, the fat content difference of variants from the addition of kidney bean flour and mung bean flour is insignificant. However, the difference is high when compared to the variant of peanut flour addition. The highest fat content is obtained with the addition of peanut flour $(0.31 \%)$. Meanwhile, the lowest fat content is found in the variant of mung bean flour addition (0.07\%). The result fits the statement of Yulifianti et al. (2014), which states that the fat content of peanut is around 44.2 to 56.0 percent for every 100 gram, which is the highest among other types of beans and nuts. The constituent fat of peanut is mostly unsaturated fat like oleic and linoleic acid (around 76 to 86 percent). Besides, the 
cooking temperature will cause the fat to turn into liquid, and its viscosity will decrease so that the fat is more natural to be released from the cell matrixes. Fat starts to melt at a temperature of 30 to 35 degrees Celcius. The above results already meet the National Standard (SNI 3818:2014), which mentions that the maximum fat content of processed meat is $10 \%$.

\subsection{WHC (Water Holding Capacity)}

Water Holding Capacity is the ability to hold water or additional water while there is the water hold effect externally, for example, meat cutting, grinding, and cooking (Lindarti, 2018). Based on observations, some water holding capacity characteristics of patties analog are as follows.

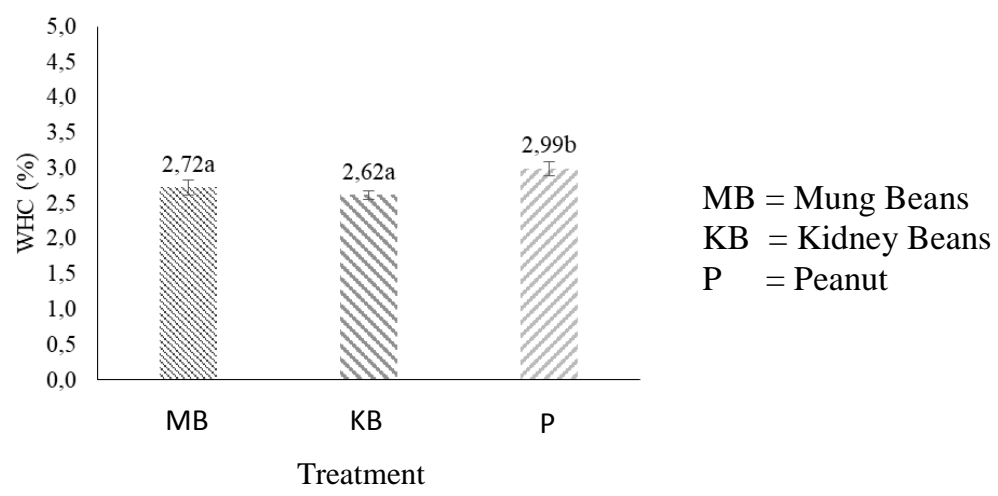

Figure 4. WHC of patties analog.

Based on Figure 4, the value of water holding capacity on both variants of kidney bean flour and mung bean flour differs insignificantly. However, the addition of peanut flour to the variant makes a significant difference to other variants. The highest water holding capacity is found in this variant as $2.99 \%$, while the lowest is in the variant of mung bean as $2.62 \%$. The high level of water holding capacity in the variant of peanut flour is due to its high protein in the composition. According to Kusnandar (2010), the water holding capacity of patty analog is affected by the amount of protein, $\mathrm{pH}$ level, ion bond, and heating process. The lower the amount of protein contained by food, the lower the water hold capacity is. The heating process in the production process of patties analog will also denature the protein. Hence, the higher the temperature, the lower the amount of water held in the patty is (Hairunnisa et al, 2016).

\subsection{Organoleptic test}

\subsubsection{Descriptive test}

The descriptive test is one of the organoleptic tests which is held to rate the products based on parametric evaluations. Some parameters to be evaluated are brightness, the odor of nut, odor of patty, taste of nut, savory taste, crusty texture, and sandy texture of the served products. The result of the descriptive test is shown in Table 2.

Based on test results in Table 2, the brightness level on both variants of mung bean flour and peanut flour differs insignificantly. However, the addition of kidney bean flour to the variant makes a significant difference to other variants. The highest brightness level 
is found on the mung bean variant as 3.13 (quite bright) and the lowest is found in kidney bean variant as 1.67 (very not bright). According to Kusumaningrum et al (2007), the brightness of a product is also affected by the number of carbohydrates contained so that the Meilard reaction is more sensitive. The reaction makes melanoidin, a compound that contributes to the brown color of a food product. Besides, the brightness level of the patties analog is affected by the baking process.

Table 2. Descriptive test of patties analog.

\begin{tabular}{cccccccc}
\hline \multirow{2}{*}{$\begin{array}{c}\text { Treat- } \\
\text { ment }\end{array}$} & Brightness & $\begin{array}{c}\text { Odor } \\
\text { of nut }\end{array}$ & $\begin{array}{c}\text { Odor } \\
\text { of } \\
\text { patty }\end{array}$ & $\begin{array}{c}\text { Taste } \\
\text { of nut }\end{array}$ & Savory & $\begin{array}{c}\text { Crusty } \\
\text { Texture }\end{array}$ & $\begin{array}{c}\text { Sandy } \\
\text { Texture }\end{array}$ \\
\hline \multirow{2}{*}{ KB } & $1,67 \pm 0,62 \mathrm{a}$ & $\begin{array}{r}2,53 \pm \\
1,06 \mathrm{a}\end{array}$ & $\begin{array}{c}2,40 \pm \\
0,91 \mathrm{a}\end{array}$ & $\begin{array}{c}2,53 \pm \\
0,92 \mathrm{a}\end{array}$ & $3,27 \pm 0,88 \mathrm{a}$ & $3,53 \pm 0,64 \mathrm{a}$ & $2,73 \pm 0,88 \mathrm{a}$ \\
\hline \multirow{2}{*}{$\mathrm{MB}$} & \multirow{2}{*}{$3,13 \pm 0,64 \mathrm{~b}$} & $\begin{array}{r}2,47 \pm \\
0,83 \mathrm{a}\end{array}$ & $\begin{array}{r}2,60 \pm \\
1,12 \mathrm{a}\end{array}$ & $\begin{array}{c}2,60 \pm \\
0,99 \mathrm{a}\end{array}$ & $3,73 \pm 0,80 \mathrm{a}$ & $3,07 \pm 0,59 \mathrm{~b}$ & $2,64 \pm 0,74 \mathrm{a}$ \\
\hline \multirow{2}{*}{$\mathrm{P}$} & \multirow{2}{*}{$2,87 \pm 1,06 \mathrm{~b}$} & $3,60 \pm$ & $2,07 \pm$ & $3,53 \pm$ & $3,53 \pm 0,99 \mathrm{a}$ & $1,67 \pm 0,49 \mathrm{c}$ & $2,40 \pm 0,83 \mathrm{a}$ \\
\hline
\end{tabular}

Numbers on the same line followed with a different letter $(a, b)$ shows a significant difference $(\mathrm{p}<0.05)$.

Nut odor as parameter shows an insignificant difference between variants of a kidney bean and mung bean flour. Otherwise, both variants show a significant difference compared to the variant of peanut flour. Patties analog with the addition of peanut flour gives strong odor of nut as 3.60 while mung bean flour addition gives the mildest odor of nut as 2.47. The strong sense of nut is caused by the high nutrition level, which is dominated by phytic acid (Astawan, 2009), and the strong beany flavor which is caused by lipoxygenase tends to make the final product less accepted (Pangastuti et al., 2013).

Patties odor shows no significant difference among all variants. All variants show results within the range of 2.07 to 2.60 .

Taste of nut in patties analog from the variants of a kidney bean and mung bean flour differs insignificantly. However, the peanut flour variant significantly different from both previous variants. The most definite taste of nut is found in the variant of peanut as 3.53 (quite strong) and the mildest is found in the variant of kidney bean as 2.53 (not strong). It is expected as peanut has a strong sense or taste.

Savory taste as a parameter in patties analog variants of a kidney bean, mung bean, and peanut shows no significant difference among all variants. Panelists rate quite savory for three variants of patties analog within the range of 3.27 to 3.73 . The savory taste of patties analog mainly is produced by the additional seasonings in production, i.e., salt, pepper, seasoning, and garlic, in which the combination creates the whole taste of savory (Hairunnisa et al, 2016).

The crusty texture as a parameter is the softness and roughness of a food product (Wiryawan, 2011). Patties analog textures are different based on their variants. Kidney bean flour addition to the patty shows the most crusty texture which is 5.35 (quite rough) while the lowest is shown in peanut flour as 1.67 (very not rough). The texture is highly affected by the addition of oyster and CMC which is able to hold the added nuts. Peanut has a rough texture and high amount of protein so that it has the ability to emulsify fat 
better hence it can also affect the texture of patties analog (Hairunnisa et al., 2016). Triatmojo (1992) states that a dough that has stable emulsion also has a better texture.

Sandy texture as a parameter in patties analog shows the insignificant difference among all variants. Panelists rate patties analog from different variants within the range of 2.40 to 2.73 (not sandy). It is expected due to an excellent sifting process that results in very smooth products.

\subsubsection{Hedonic test}

The hedonic test is one of the organoleptic tests that is done to rate products based on parametric evaluations of panelists' preference level. Some parameters that evaluated are brightness level, the odor of nut, odor of patty, taste of nut, savory taste, crusty texture, and sandy texture. The test result is shown in Table 3.

Table 3. Organoleptic-Hedonic Test of Patties Analogue Test Result

\begin{tabular}{ccccccccc}
\hline \multirow{2}{*}{$\begin{array}{c}\text { Treat- } \\
\text { ment }\end{array}$} & Brightness & $\begin{array}{c}\text { Odor } \\
\text { of } \\
\text { Nut }\end{array}$ & $\begin{array}{c}\text { Odor } \\
\text { of } \\
\text { Patties }\end{array}$ & $\begin{array}{c}\text { Taste } \\
\text { of } \\
\text { Nut }\end{array}$ & $\begin{array}{c}\text { Savory } \\
\text { Taste }\end{array}$ & $\begin{array}{c}\text { Crusty } \\
\text { Texture }\end{array}$ & $\begin{array}{c}\text { Sandy } \\
\text { Texture }\end{array}$ & $\begin{array}{c}\text { Overall } \\
\text { Result }\end{array}$ \\
\hline \multirow{2}{*}{ KB } & $2,76 \pm 1,23 \mathrm{a}$ & $3,08 \pm$ & $2,68 \pm$ & $2,84 \pm$ & $2,88 \pm 1,05 \mathrm{a}$ & $3,00 \pm 1,08 \mathrm{a}$ & $2,76 \pm 0,88 \mathrm{a}$ & $2,76 \pm 0,88 \mathrm{a}$ \\
& & $0,76 \mathrm{a}$ & $0,90 \mathrm{a}$ & $0,85 \mathrm{a}$ & & & & \\
MB & $3,36 \pm 0,86 \mathrm{a}$ & $3,32 \pm$ & $3,40 \pm$ & $3,28 \pm$ & $3,44 \pm 0,82 \mathrm{a}$ & $3,12 \pm 0,88 \mathrm{a}$ & $3,00 \pm 0,76 \mathrm{a}$ & $3,36 \pm 0,86 \mathrm{a}$ \\
& & $0,90 \mathrm{a}$ & $0,91 \mathrm{a}$ & $0,89 \mathrm{~b}$ & & & & \\
$\mathrm{P}$ & $3,48 \pm 1,08 \mathrm{~b}$ & $2,84 \pm$ & $2,80 \pm$ & $2,28 \pm$ & $2,96 \pm 1,06 \mathrm{a}$ & $2,80 \pm 1,12 \mathrm{a}$ & $2,84 \pm 0,99 \mathrm{a}$ & $2,68 \pm 0,99 \mathrm{~b}$ \\
\hline
\end{tabular}

Numbers on the same line followed with a different letter $(a, b)$ shows a significant difference $(\mathrm{p}<0.05)$.

The brightness of patties analog insignificantly differs between variants of a kidney bean and mung bean. However, both previous variants show a significant difference in brightness to the variant of peanut. Panelists rate the highest score of brightness to the patty analog made of peanut as 3.48 (quite fond of), and the lowest is to the one made of kidney bean as 2.76 (dislike). The brightness level of a food product is affected by the natural color of the comestibles. Kidney bean tends to have a dark color in nature so that the color of the patty made of kidney bean also tends to turn dark and not bright in color after it got baked.

The odor of nut in patties analog of all variants differs insignificantly. Panelists rated the highest score based on the odor of nut to the variant of mung bean as 3.32 (quite fond of) and the lowest to peanut as 2.84 (dislike). Panelists tend to dislike the patty analog made of a peanut since it has too strong in the smell of the nut.

According to Meilgard et al., (1999), odor or smell is the attribute of organoleptic that can be rated from the senses of smell. The hedonic test result shows that the patty analog' odor score from panelists is average to the variants of a kidney bean and mung bean. Nevertheless, both previous variants show a big difference in the score to the variant of peanut patty analog. The highest score is given to the variant of mung bean as 3.40 (quite fondly), while the lowest is to kidney bean as 2.68 (disliked). Radiati (2016) states that the addition of peanut gives the typical strong odor of nut. The strong odor of peanut tends to be disliked, due to the beany flavor or unpleasant smell caused by lipoxygenase. 
The enzyme of lipoxygenase can be non-activated by giving treatments such as soaking in water, grinding, and repeating processes of heating (Muawanah, 2007).

Savory taste in all variants differs insignificantly. The most favorite savory taste is found in the variant of mung bean as 3.44 (quite fondly), and the most disliked is in the variant of kidney bean as 2.88 (disliked). The savory taste of patties analog can be obtained from the type of nuts that has a high amount of protein or fat to enhance the savory taste or from the interactions with other ingredients (Kurnianingtyas, 2014).

The taste of nut in patties analog differs insignificantly between the variants of mung bean and peanut. However, both previous variants differ significantly from the variant of a kidney bean. Panelists like the variant of mung bean the most as 3.28 (quite fondly) while disliking the variant of the peanut as 2.28 (dislike) the most. This is expected due to the proportion of nut taste in peanut is too strong. So, the panelist tends to dislike it, although it is already mixed with other seasonings.

The crusty texture of the patties analog shows an insignificant difference in all variants. The lowest score is given to the variant of peanut as 2.80 (disliked), while the variant of mung bean has the highest score as 3.12 (quite fondly). The water content of the added materials also affects the texture of the patties analog. High content of water makes the texture to be more soft (Malindo et al., 2016). Besides, the texture of a food product is also affected by the water holding capacity (Afrisanti, 2010). Peanut, which tends to have more oil, tends to make the texture of the patty analog softer.

The sandy texture of all variants also shows an insignificant difference. Panelists rated the highest score of sandy texture to the variant of mung bean as 3.00 (quite fondly) and the lowest to the variant of kidney bean as 2.76 (disliked). This is likely to happen due to the incomplete and imperfect sorting and sifting process. It caused the peeling skin, and the husk of the nuts still linger and got processed. Then, it left the sandy texture when the patty analog was consumed.

As overall contentment for the patty analog variants, the result differs insignificantly between the variants of a kidney bean and mung bean. Nonetheless, the result is different significantly between both previous variants with the variant of peanut. Overall, panelists like the mung bean variant the most as the score is 3.36 while disliking the peanut variant as the score is 2.68 . Hence, authors consider from the organoleptic properties that the mung bean variant is the most-liked variant of patty analog based on its brightness, odor of nut, the odor of the patty, taste of nut, savory taste, and sandy texture.

\section{CONCLUSIONS}

From the water content analysis, the lowest is found in the variant of peanut as $18.44 \%$. Meanwhile, the highest is found in the variant of kidney bean as $25.88 \%$. The highest ash content is obtained from the variant of mung bean as $0.08 \%$ and the lowest from the variant of peanut as $0.07 \%$. The highest fat content is found in peanut variant as $0.31 \%$ and the lowest is in kidney bean as $0.08 \%$. Based on Water Holding Capacity (WHC) analysis, the highest is found from the patty analog made of peanut as $2.99 \%$ while the lowest is from the one made of $2.62 \%$. Based on the organoleptic test result, the most liked variant of patty analog based on panelists' preference is the one made of mung bean flour. 


\section{BIBLIOGRAPHY}

Afrisanti D. W. (2010). Kualitas Kimia dan Organoleptik Nugget Daging Kelinci Dengan Penambahan Tepung Tempe. Skripsi. Fakultas Pertanian. Universitas Sebelas Maret Surakarta.

AOAC. (1995). Official Methods of Analysis of Association of Official. Analytical Chemist. $A O A C$ International. Virginia USA

AOAC. (2005). Official Methods of Analysis of The Association of Official. Analytical Chemist. AOAC Inc., Washington.

Astawan M. (2009). Sehat dengan Hidangan Kacang dan Biji-Bijian. Jakarta: Penerbit Swadaya.

Gómez-guillén, M., Turnay, J., Fernández-Díaz, M., Ulmo, N., LizaKBe, M., \& Montero, P. (2002). Structural and physical properties of gelatin extracted from different marine species: a comparative study. Food Hydrocolloids, 16(1), 25-34.

Hairunnisa O, E. Sulistyowati dan D. Suherman. (2016). Pemberian Kecambah Kacang Hijau (Tauge) terhadap Kualitas Fisik dan Uji Organoleptik Bakso Ayam. Jurnal sains peternakan. 11 (1) : 39-47.

Handayani, N. A., Santosa, H., Kusumayanti, H. (2014). Fortifikasi inorganik zink pada tepung ubi jalar ungu sebagai bahan baku bubur bayi instan. Reaktor, 15(2), 111-116

Hudaya S. (1999). Modul Perkuliahan. Teknologi Pangan. Fakultas Pertanian, Universitas Padjajaran. Jatinagor.

Koswara, S. (1995). Teknologi Pengolahan Kedelai. Jakarta: Pustaka Sinar Harapan.

Kusnadi, D.C. Bintoro, V.P, dan A.N. Al-Baari. (2012). Daya ikat air tingkat kekenyalan dan kadar protein pada bakso kombinasi daging sapid an daging kelinci. Jurnal Aplikasi Teknologi Pangan. 1:2

Kusnandar, F. (2010). Kimia Pangan: Komponen Makro. Jakarta: Dian Rakyat.

Kusumaningrum A dan Winiati P Rahayu. (2007). Penambahan Kacang-kacangan dalam formulasi makanan pendamping air susu ibu (MO-ASI) berbahan dasar pati aren (Arenga pinnata (Wurmb) Merr)). Jurnal Teknologi dan Industri Pangan. 18 (2) : 73-80.

Lindriati T, Herlina dan Jefrinka Nelza E. (2018). Sifat Fisik Daging Analog Berbahan Dasar Campuran Tepung Porang (Amorphophallus Oncophyllus) Dan Isolat Protein Kedelai. Jurnal Teknologi Pertanian.Vol 22 (2).

Malindo R, Edison dan N Ira Sari. (2010). Pengaruh Penambahan Tepung Kacang Hjau (Vigna Radiata) Terhadap Mutu Bakso Ikan Lele Dumbo (Clarias Gariepinus). Jurnal Perikanan. $2(11)$.

Muawanah, A. (2007). Pengaruh lama inkubasi dan variasi jenis starter terhadap kadar gula, asam laktat, total asam dan pH yoghurt susu kedelai. Jurnal Valensi. 1 (1) : $1-6$.

Nurhadi, Bambang., S Rahimah dan I Munawaroh. (2010). Kajian Daya Rehidrasi Sugar Coated Puffed Cereal dengan BeKBagai Konsentrasi Larutan Sukrosa. Skripsi. Bandung: Universitas Padjajaran.

Pangastuti, H. A., D. R. Affandi dan D. Ishartani. (2013). Karakteristik sifat fisik dan kimia tepung kacang merah (Phaseolus vulgaris L.) dengan beberapa perlakuan pendahuluan. J. Teknosains Pangan. 2 (1) : 20 - 29.

Radiati A dan Sumarto. (2016). Analisis Sifat Fisik, Sifat Organoleptik, dan Kandungan Gizi pada Produk Tempe dari Kacang Non-Kedelai. Jurnal Aplikasi Teknologi Pangan 5 (1) : $16-22$. 
SNI. (1995). Syarat Mutu Bakso dan Formulasi Bakso (SNI 01-3818- 1995). Jakarta: Badan Standarisasi Nasional.

Sudarmadji, S; B. Haryono dan Suhardi. (1989). Analisa Bahan Makanan dan Pertanian. Yogyakarta: Penerbit Liberty.

Triatmojo, S. (1992). Pengaruh Pengantian Daging Sapi dengan Daging Kerbau, Ayam dan Kelinci pada Komposisi dan Kualitas Bakso. Laporan Penelitian Fakultas Peternakan, Universitas Gadjah Mada, Yogyakarta.

Wahyuningsih, Sri. (2014). Komposisi Proksimat, Tingkat Kekerasan dan Daya Terima Brownies yang dibuat dengan Menggunakan Jenis Telur yang BeKBeda. Jurnal. Surakarta: Fakultas Ilmu Kesehatan. Universitas Muhammadiyah Surakarta.

Winarno, F.G., (2004). Kimia Pangan dan Gizi. Jakarta: Gramedia Pustaka Utama.

Yulifianti et al. (2014). Teknologi Pengolahan dan Produk Olahan Kacang Tanah. Balai Penelitian Tanaman Aneka Kacang dan Umbi. Malang Balai Besar Penelitian dan Pengembangan Pascapanen Pertanian. Bogor. 376. 